\title{
PENGARUH PENERAPAN MODEL COOPERATIVE LEARNING TIPE JIGSAW TERHADAP HASIL BELAJAR DAN KEDISIPLINAN BELAJAR SISWA DALAM PEMBELAJARAN PKN \\ DI KELAS VIII SMP KARYA AGUNG \\ KOTA BINJAI TAHUN PELAJARAN \\ 2018/2019
}

\author{
Azmy \\ STKIP Budidaya Binjai
}

\begin{abstract}
ABSTRAK
Penelitian ini bertujuan untuk mengetahui ada atau tidaknya pengaruh penerapan model cooperative learning tipe jigsaw terhadap hasil belajar dan kedisiplinan belajar siswa dalam pembelajaran PKN di kelas VIII SMP Karya Agung kota Binjai tahun pelejaran 2018/2019. Penelitian ini adalah penelitian Quasi Eksperimen. Sampel dalam penelitian ini adalah siswa kelas VIII SMP Karya Agung Binjai tahun pelajaran 2018/2019 sebanyak 25 siswa sebagai kelas ekperimen dan 23 siswa sebagai kelas kontrol. Berdasarkan hasil analisis data diketahui nilai $t$ hitung $>t$ tabel sehinnga dapat diambil kesimpulan bahwa terdapat pengaruh penerapan model cooperative learning tipe jigsaw terhadap hasil belajar dan kedisiplinan belajar siswa dalam pembelajaran PKN di kelas VIII SMP Karya Agung kota Binjai tahun pelejaran 2018/2019.
\end{abstract}

kata kunci : cooperative learning tipe jigsaw, hasil belajar pkn

\section{PENDAHULUAN}

Hasil belajar siswa dan Kedisiplinan belajar kelas VIII SMP Karya Agung Binjai dalam pelajaran PKn masih rendah terlihat saat berlangsungnya kegiatan belajar terdapat beberapa siswa yang masih belum faham dan masih ribut di sana sini .Guru berulang kali menjelaskan tentang pelajaran tetapi siswa cenderung berbicara dengan teman nya. Selain itu, terdapat beberapa siswa yang tidak mengerjakan tugas dengan sungguh-sungguh ketika mengerjakan sendiri. Cooperative Learning tipe jigsaw sangat baik terhadap hasil belajar pendidikan kewarganegaraan ditinjau dari sikap social siswa. Model pembelajaran mengukur dari beberapa unsur yaitu (1) Terdapat perbedaan hasil belajar pada siswa yang mengikutimodel pembelajaran kooperatif tipe jigsaw dengan siswa yang mengikuti modelpembelajaran konvensional,(2) Terdapat pengaruh intraksi antara penerapan modelpembelajaran kooperatif tipe jigsaw dan sikap social terhadap hasil belajar PKn, (3) Padasiswa yang memiliki sikap social tinggi, terdapat perbedaan hasil belajar siswa antarayang mengikuti model pembelajaran Cooperative Learningtipe jigsaw dengan siswa yang mengikutimodel pembelajaran kompensional, 
dan (4) Pada siswa yang mengikuti sikap social rendah terdapat perbedaan hasil belajar pada siswa yang mengikuti model pembelajaran Cooperative Learning tipe jigsaw dengan siswa yang mengikuti model pembelajaran konvensional.

Cooverative learning digunakan untuk mengatasi beberapa msalah antara lain (1)Siswa kurang aktif dalam pembelajaran, ditandai dengan kegiatan pembelajaran didominasi oleh guru. (2)terlihat saat mengikuti proses pembelajaran siswa tidak mengerjakan tugas dengan sungguh sungguh bahkan kurang disiplin dalam mengikuti proses pembelajaran. (3)Hasil Belajar dan Kedisiplinan siswa dalam mengikuti pembelajran PKn masih rendah. (4)Guru belum menerapkan model pembelajaran yang tepat dalam kegiatan pembelajaran PKn. (1) Pada saat itu masalah dibatasi dengan memperbaiki hasil belajar dan Kedisiplinan belajar siswa pada mata pelajaran PKn menggunakan Model Cooperative Learning Tipe Jigsawpada siswa kelas VIII Smp Karya Agung Binjai. Dengan tujuan Untuk mendeskripsikan hasil belajar siswa dalam pelajaran PKn di kelas VIII SMP Karya Agung Binjai dengan menggunakan Model Cooperative Learning Tipe Jigsaw. (2)Untuk mendeskripsikan Kedisiplinan belajar siswa dalam pelajaran PKn di kelas VIII SMP Karya Agung Binjai dengan menggunakan Model Cooperative Learning Tipe Jigsaw.

Menurut Permendiknas No.22 Tahun 2006 tentang standar Isi Pendidikan Nasional, PKn merupakan mata pelajaran yang memfokuskan pada pembentukan warga negara yang memahami dan mampu melaksanakan hak-hak dan kewajibannya untuk menjadi warga negara Indonesia yang cerdas, terampil dan berkarakter yang diamanatkan oleh Pancasila dan UUD 1945. PKn adalah aspek pendidikan politik yang fokus materinya peranan warga negara dalam kehidupan bernegara yang kesemuanya itu diproses dalam rangka untuk membina peranan tersebut sesuai dengan ketentuan Pancasila dan UUD 1945 agar menjadi warga negara yang dapat diandalkan oleh bangsa dan negara.

Belajar dan pembelajaran adalah suatu kegiatan yang tak terpisahkan dari kehidupan manusia. Dengan belajar manusia bisa mengembangkan potensipotensi yang dibawa sejak lahir. Tanpa belajar manusia tidak mungkin dapat memenuhi kebutuhannya tersebut. Kebutuhan belajar dan pembelajaran dapat terjadi dimana-mana, misalnya di lingkungan keluarga, sekolah, dan masyarakat. Kebutuhan manusia akan 
belajar tidak akan pernah berhenti selama manusia ada di muka bumi ini. Hal itu disebabkan karena dunia dan isinya termasuk manusia selalu berubah. Belajar merupakan kegiatan yang dilakukan seseorang agar dapat mencapai kompetensi yang diinginkan. Model pembelajaran adalah suatu perencanaanatau pola yang digunakan sebagai pedoman dalam merencanakanpembelajaran di kelas atau pembelajaran tutorial. Model pembelajaranmengacu pada pendekatan pembelajaran yang akan digunakan,termasuk di dalamnya tujuan-tujuan pengajaran, tahap-tahap dalamkegiatan pembelajaran, lingkungan pembelajaran, dan pengelolaan kelas.

Cooperative learning berasal dari kata cooperative yang artinya memaksimalkan belajar siswa untuk meningkatkan akademik dan pemahaman baik secara individu maupun secara kelompok serta saling membantu satu sama lain. model pembelajaran cooperativelearning merupakan salah satu pembelajaran yang mendukung pembelajaran konstektual. Jadi pembelajaran cooperative learning tipe jigsaw adalah model pembelajaran dengan menggunakan pengkelompokkan /tim kecil yaitu yang terdiri antara empat, enam, bahkan sampai delapan orang yang mempunyai latar belakang yang berbeda. Dan sistem penilaian dilakukan terhadap kelompok dan setiap kelompok akan memperoleh penghargaan, jika kelompok dapat menunjukkan prestasi yang persyaratkan. Karakteristik strategi pembelajaran kooperatif, terdiridari :Pembelajaran Secara Tim Pembelajaran kooperatif adalah pembelajaran secara tim. Tim merupakan tempat untuk mencapai tujuan. Karena itu, tim harus mampu membuat siswa belajar. Semua anggota tim harus saling membantu untuk memcapai tujuanpembelajaran. Didasarkan pada Manejemen KooperatifManajemen mempunyai empat fungsi pokok, yaitu: (1) Fungsi perencanaan yang menunjukkan bahwapembelajaran kooperatif memerlukan perencanaan yangmatang agar proses pembelajaran berjalan secara efektif. (2) Fungsi pelaksanaan menunjukkan bahwa pembelajarankooperatif harus dilaksanakan sesuai denganperencanaan, melalui langkah-langkah pembelajaranyang sudah ditentukan termasuk ketentuan-ketentuanyang telah disepakati bersama. (3) Fungsi organisasi menunjukkan bahwa pembelajaran kooperatif adalah pekerjaan bersama setiap anggota kelompok sehingga perlu diatur tugas dan tanggung jawab setiap anggota kelompok. (4) Fungsi control menunjukkan bahwa dalam pembelajaran kooperatif perlu ditentukan kriteria keberhasilan baik melalui tes maupun nontes. 
Pengertian hasil belajar adalah kemampuan-kemampuan yang dimiliki siswa setelah menerima pengalaman belajarnya, sedangkan menurut Gagne hasil belajar harus harus didasarkan pada pengamatan tingkah laku melalui stimulus respon. Hasil belajar berkenaan dengan kemampuan siswa di dalam memahami materi pelajaran. Menurut Hamalik mengemukakan, "hasil belajar pola-pola perbuatan, nilai-nilai, pengertianpengertian, sikap-sikap, apresiasi, ablititas dan keterampilan”. Hasil belajar tampak sebagai terjadi perubahan tingkah laku pada diri siswa yang dapat diamati dan diukur dalam bentuk perubahan pengetahuan, sikap dan keterampilan. Perubahan tersebut dapat diartikan terjadinya peningkatan dan pengembangan yang lebih baik dibandingkan dengan sebelumnya, misalnya dari tidak tahu menjadi tahu, sikap kurang sopan menjadi sopan dan sebagainya. Disiplin adalah merupakan salah satu faktor penting dalam mencapai suatu tujuan, baik itu tujuan organisasi maupun tujuan individu. Dengan kata lain disiplin merupakan salah satu aspek dari kehidupan manusia, selama manusia tersebut mempunyai tujuan yang hendak dicapai Untuk memperjelas pengertian disiplin ini dikemukakan beberapa pendapat dari para ahli menyebutkan bahwa "Disiplin adalah ketaatan pada aturan dan tata tertib". menyebutkan bahwa "Disiplin adalah kepatuhan seseorang dalam mengikuti peraturan atau tata tertib karena didorong oleh adanya kesadaran yang ada pada hatinya". mengemukakan bahwa "Disiplin yang baik mengandung ketundukan anak didik terhadap peraturan-peraturan yang tanpa menyukarkan proses belajar" Dari beberapa pendapat tersebut di atas, dapat disimpulkan bahwa adanya beberapa unsur yang terdapat dalam pengertian disiplin, bahwa disiplin adalah ketaatan atau kepatuhan seseorang terhadap peraturan. Ketaatan ini dilandasi oleh suatu kesadaran. Ketaatan ini timbul untuk mencapai suatu tujuan.

Kerangka Konseptual nya adalah Pendidikan kewarganegaraan adalah pendidikan yang mengingatkan kita akan pentingnya nilai-nilai hak dan kewajinan suatu warga negara agar setiap hal yang di kerjakan sesuai dengan tujuan dan cita-cita bangsa dan tidak melenceng dari apa yang di harapkan. Karena di nilai penting, pendidikan ini sudah di terapkan sejak usia dini di setiap jenjang pendidikan mulai dari yang paling dini hingga pada perguruan tinggi agar menghasikan penerus -penerus bangsa yang berkompeten dan siap menjalankan hidup berbangsa dan bernegara. Kemampuan dan kedisiplinan siswa merupakan salah satu tujuan penting dalam pembelajaran PKn. Salah 
satu model pembelajaran yang dapat mengembangkan kemampuan dan kedisiplinan siswa adalah model pembelajaran Cooperatif. Model pembelajaran kooperatif merupakan salah satu model pembelajaran yanguntut siswa agar bisa berperan aktif pada sebuah kelompok dalam proses pembelajaran. Salah satu model pembelajaran Cooperatif adalah model pembelajaran Cooperative Learning Tipe Jigsaw yang menuntut adanya keaktifan siswa sebagai upaya untuk meningkatkan kemampuan dan kedisiplinan siswa dalam mata pelajaran PKn. Ada tiga tahapan yang dilalui siswa dalam model pembelajaran Cooverative Learning Tipe Jigsaw. Tahap pertama, siswa dituntut untuk berfikir secara mandiri dalam menyelesaikan masalah atau soal yang diberikan oleh guru dalam tahap ini siswa akan berusaha memahami terlebih dahulu tentang permasalahan yang di berikan. Selanjutnya tahap kedua siswa di pasangkan dengan kelompoknya untuk mendiskusikan hasil pemikiran permasalahan pada tahap pertama. Tahap ini berperan penting karena dengan adanya diskusi siswa akan lebih mudah bertukar ide atau pendapat masing masing kepada kelompok nya. Dan tahap akhir pada model inimelatih keberanian siswa untuk berbagi informasi , bertanya, atau mengungkapkan pendapatnya dengan seluruh kelas tantang apa yang di diskusikan dengan kelompok nya.

\section{METODE}

Penelitian ini dilaksanakan di kelas VIII SMP Karya Agung Binjai Alasan pemilihan tempat adalah Lokasi yang tidak jauh dari tempat peneliti,Lokasi tempat mengajar peneliti, danbelum pernah ada penelitian yang di lakukan di sekolah tersebut dengan model pembelajaran Cooperative Learning Tipe Jigsaw. Penelitian ini menggunakan metode kuantitatif eksperimen, dengan rancangan rancangan penelitian sebagai dasar penelitian untuk membedakan pengaruh model pembelajaran Cooperative Learning Tipe Jigsaw Terhadap Hasil belajar dan kedisiplinan belajar siswa SMP Karya Agung binjai kelas VIII. Penelitian ini melibatkan dua kelas yaitu kelas eksperimen VIIIs 1 dan kelas eksperimen VIII 2 Yang diberi perlakuan berbeda. Pada kelas eksperimen VIII 1 di beri perlakuan dengan menggunakan model pembelajaran Cooperative Learning Tipe Jigsaw. Sedangkan kelas eksperimen VIII 2 di beri perlakuan pengajaran dengan menggunakan model pembelajaran langsung. 
Populasi adalah wilayah generalisasi yang terdiri atas: obyek/subyek yang mempunyai kualitas dan karakteristik tertentu yang ditetapkan oleh peneliti untuk dipelajari dan kemudian ditarik kesimpulan. Adapun populasi yang akan diambil dalam penelitian ini adalah siswa kelas VIII SMP Karya Agung Binjai dengan jumlah populasi sebanyak 2 Kelas. Sampel adalah :"sebagian yang diambil dari populasi dengan menggunakan metode tertentu. Sampel juga dapat diartikan bagian dari populasi yang menjadi objek penelitian. Pengambilan sampel adalah dengan mengambil semua siswa di kelas yang berbeda yang dipilih secara semu, yaitu setiap anggota populasi berhak menjadi sampel penelitian. Satu kelas di jadikan sebagai kelas eksperimen A (Kelas VIII) yaitu kelas yang menggunakan medel pembelajaran Cooperative Learning Tipe Jigsaw, Kelas lainya di jadikan kelas Eksperimen B (VIII 2) yaitu kelas yang menggunakan model pembelajaran langsung.

Variabel Penelitian adalah atau apa saja yang menjadi titik perhatian dalam penelitian. Adapun Variabel dalam Penelitin ini adalah variabel bebas adalah variabel yang dibuat bebas/berpariasi. Variabel bebas dalam hal ini yaitu Model pembelajaran Cooperative Learning Tipe Jigsaw. Diawali dengan guru memberikan masalah mengenai materi yang akan di ajarkan, kemudian guru memerintahkan siswa untuk berkelompok dan mendpada mendiskusikan penyelesaian masalah dan tahap yang terahkhir adalah siswa membagi hasil diskusinya kepada siswa di depan kelas. Hasil belajar adalah kemampuan yang dimiliki oleh siswa setelah belajar, yang wujudnya berupa kemampuan kognitif, afektif, dan psikomotor yang disebabkan oleh pengalaman. kedisiplinan belajar adalah suatu kondisi belajar yang tercipta dan terbentuk melalui proses dari serangkaian sikap dan perilaku peribadi atau kelompok yang menunjukan nilai-nilai ketaatan, kepatuhan, kesetiaan, keteraturan dan ketertiban. Pengumpulan data dengan metode tes dan angket kedisiplinan dengan menggunakan uji validitas realibilitas dan uji regresi sederhana.

\section{HASIL DAN PEMBAHASAN}

Dalam penelitian ini, data yang dideskripsikan peneliti meliputi data hasil belajar siswa pada pendidikan pancasila kewarganegaraan oleh siswa kelas VIII SMP Karya Agung tahun pelajaran 2018/2019. Penelitian ini menggunakan jenis 
penelitian eksperimen semu (quasi eksperimental) dengan desaian "randomized control grup prestest-pascatest desaian" yakni menempatkan sampel penelitian kedalam dua kelompok kelas yang dibedakan menjadi kategori kelas eksperimen dan kelas kontrol. Tujuan utama dalam penelitian ini adalah untuk mengetahui pengaruh model pembelajaran tipe jigsaw terhadap hasil belajar siswa pada pendidikan kewarganegaraan siswa kelas VIII SMP Karya Agung Binjai Tahun pelajaran 2018/2019 pada kelas eksperimen dan metode konvesional pada siswa kelas kontrol.

Data penelitian diperoleh dari hasil pretest, posttest dan angket. Penelitian merupakan penelitian eksperimen semu yang melibatkan dua kelas yang diberi perlakuan yang berbeda, yaitu kelas eksperimen yang diberikan perlakuan dengan menggunkan model pembelajaran model pembelajaran tipe jigsaw dan kelas kontrol yang diberi perlakukan menggunakan metode konvesional. Jumlah siswa pada kelas eksperimen 25 siswa dan kelas kontrol berjumlah 23 siswa. Sebelum materi diajarkan atau sebelum adanya perlakuan pada setiap kelas, terlebih dahulu siswa diberi pretest untuk mengetahui kemampuan awal siswa terhadap materi yang diteliti pada kelas eksperimen dan kelas kontrol, setelah proses pembelajaran menggunakan model pembelajaran tipe jigsaw selanjutnya adalah memberikan posttest dan angket kedisiplinan siswa. Adapun rangkuman nilai pretest, posttest, dan angket dari kelas eksperimen dan kelas kontrol disajikan pada tabel deskcriptive statistics yang merupakan output dari SPSS 16.

Dari analisis data yang telah dilakukan dapat ditarik suatu kesimpulan bahwa penerapan model pembelajaran tipe jigsaw berpengaruh positif terhadap hasil belajar dan kedisiplinan siswa kelas VIII SMP Karya Agung Binjai tahun pelajaran 2018/2019.

\section{SIMPULAN}

Berdasarkan hasil penelitian yang diuraikan maka dapat diambil kesimpulan bahwa terdapat pengaruh antara model pembelajaran Cooperative Learning Tipe Jigsaw dalam pelajaran PPKn terhadap hasil belajar dan kedisiplinan siswa di kelas VIII Smp Karya Agung Binjai. 


\section{REFERENSI}

Kompri, 2014. Manajemen Sekolah Teori dan Praktek. Bandung: alfabeta. Langgulung,

Hasan. 2014. Manusia Pendidikan.Jakarta: PT Al -Husna Baru.

Moleong, Lexy. 2014. Metode Penelitian Kualitatif .Bandung: Rosda.

Mustari, Mohamad. 2014.Nilai karakter Refleksi untuk Pendidikan.Jakarta: rajawali Pers.

Nazir, Moh. 2014.Metode Penelitian. Bogor: Ghalia Indonesia.

Naim,Ngainun.2012. Optimalisasi Peran Pendidikan dalam Pengembangan Ilmu \& Pembentukan Karakter Bangsa, Yogyakarta: Ar-Ruzz Media.

Rifa'i, Muhammad. 2013.Sosiologi Pendidikan.Yogyakarta: Ar-ruzz media

S, Azwar. 2013. Reabilitas dan Validitas. Yogyakarta: Pustaka Pelajar.

Schaefer,Charles. 2011. Membimbing Mendidik dan Mendisiplinkan Anak Secara Efektif. Jakarta: Radar Jaya Offset.

Silvia, rimm. 2013. Mendidik dan Menerapkan Disiplin pada Anak Prasekolah.Jakarta: Grame

Soedjono.2014. Dasar-Dasar Tata Tertib Sekolah.jakarta: PT Raja Grafindo Persada.

Sukmadinata syaodih nana . 2010. Metode Penelitian Pendidikan. Bandung : PT Remaja Rosdakarya

Suryosubroto. 2016. Menejemen pendidikan sekolah. Jakarta: PT Reneka Cipta.

Tulus Tuu, 2013. peran disiplin Pada Prilaku dan Prestasi siswa. Jakarta: Grafindo.

Wiyani, Ardy, Novan.2016. Manajemen Kelas.Yogyakarta: Ar- Ruzz Media: Angkasa.

Undang- undang: Undang-Undang Republik Indonesia No.20 Tahun 2003 tentang Sistem Pendidikan. 